\title{
Biokaasulaitoksen käsittelyjäännöksen, lannoituksen ja puna- apilapitoisuuden vaikutus nurmen satoon ja metaanintuottopotentiaaliin
}

\author{
Piia Kekkonen ${ }^{1)}$, Maarit Hyrkäs ${ }^{1)}$, Perttu Virkajärvii ${ }^{1)}$, Ville Pyykkönen ${ }^{2)}$, Jenni Airaksinen ${ }^{1)}$, Satu \\ Ervasti $^{3)}$ ja Sari Luostarinen ${ }^{4)}$ \\ ${ }^{1)}$ Luonnonvarakeskus, Vihreä teknologia, Halolantie 31 A, 71750 Maaninka, etunimi.sukunimi@luke.fi \\ ${ }^{2)}$ Luonnonvarakeskus, Uudet liiketoimintamahdollisuudet, Halolantie 31 A, 71750 Maaninka, \\ etunimi.sukunimi@luke.fi \\ ${ }^{3)}$ Luonnonvarakeskus, Uudet liiketoimintamahdollisuudet, Tietotie 2, 31600 Jokioinen, \\ etunimi.sukunimi@luke.fi \\ ${ }^{4)}$ Luonnonvarakeskus, Uudet liiketoimintamahdollisuudet, Latokartanonkaari 9, 00790 Helsinki, \\ etunimi.sukunimi@luke.fi
}

\section{Tiivistelmä}

Ravinteiden hyötykäyttö on yksi taloudellisen ja ympäristöystävällisen maatalouden lähtökohtia. Tämän tutkimuksen tarkoituksena oli selvittää, kuinka tehokkaasti ravinteita voidaan kierrättää, kun nurmea tuotetaan biokaasun raaka-aineeksi mahdollisimman pienillä ostopanoksilla. Kokeessa ravinnelähteinä käytettiin biokaasureaktorin käsittelyjäännöstä, väkilannoitteita ja biologista typensidontaa. Tarkastelussa ovat vuodet 2013 - 2015 ja koe toteutettiin Luonnonvarakeskus Maaningan toimipisteessä.

Koe toteutettiin osaruutukokeena neljänä kerranteena. Pääruutuna olivat timotei-nurminataseos sekä puna-apilapitoinen timotei-nurminataseos. Osaruutuna oli neljä erilaista lannoitusstrategiaa seuraavasti: 1) ei lannoitusta 2) käsittelyjäännös toiselle sadolle 3) $50 \mathrm{~kg} \mathrm{~N} \mathrm{1.} \mathrm{sadolle,} \mathrm{käsittelyjäännös}$ ja $50 \mathrm{~kg} \mathrm{~N}$ toiselle sadolle ja 4) $100 \mathrm{~kg} \mathrm{~N} \mathrm{1.} \mathrm{sadolle,} \mathrm{käsittelyjäännös} \mathrm{ja} 50 \mathrm{~kg} \mathrm{~N}$ toiselle sadolle. Käsittelyjäännöstä levitettiin noin $30 \mathrm{t} \mathrm{ha}$ ja lisätyppi annettiin Suomensalpietarina. Käsittelyjäännöstä saatiin biokaasulaitoksesta, jonka syötteenä oli käytetty naudan lietelantaa ja timoteinurminatasäilörehua. Sadot korjattiin kaksi kertaa kesässä ja korjuun yhteydessä määritettiin kuiva-ainesato. Korjuu ajoitettiin apilanurmella ja heinänurmella kasvuolosuhteiden ja kasvilajien kehitysasteen perusteella. Näytteistä määritettiin D-arvo, typpipitoisuus sekä sulamaton kuitu (iNDF) NIR-menetelmällä ja metaanintuottopotentiaali sekä kuiva-ainetta $\left(\mathrm{m}^{3} \mathrm{CH}_{4} \mathrm{t}^{-1} \mathrm{TS}\right)$ että orgaanista kuiva-ainetta $\left(\mathrm{m}^{3} \mathrm{CH}_{4} \mathrm{t}^{-1}\right.$ VS) kohti. Lisäksi laskettiin nurmen metaanintuottopotentiaali hehtaaria kohden. Kasvuston apilapitoisuus arvioitiin kasvuston kalsiumpitoisuuden avulla vertaamalla sitä puhtaiden apila- ja heinänäytteiden kalsiumpitoisuuteen.

Apilanurmi tuotti kokeessa paremman kuiva-ainesadon kuin pelkkä heinänurmi. Lannoituksella saatiin nostettua heinänurmen satoa, mutta 1. sadon N-lannoituksen nosto $50 \mathrm{~kg}$ :sta $100 \mathrm{~kg}$ :aan ei enää lisännyt satoa. Lannoittamattomalla heinänurmella kesän kokonaissato oli keskimäärin 5020 $\mathrm{kg} \mathrm{ka} \mathrm{ha}{ }^{-1}$, kun taas korkeimmalla lannoitustasolla satoa saatiin keskimäärin $9720 \mathrm{~kg} \mathrm{ka} \mathrm{ha-1}$. Apilanurmella ilman lannoitusta kokonaiskuiva-ainesato oli keskimäärin $8920 \mathrm{~kg} \mathrm{ka} \mathrm{ha}{ }^{-1}$. Korkeimmalla lannoitustasolla apilanurmen satotaso oli keskimäärin $11580 \mathrm{~kg} \mathrm{ka} \mathrm{ha}^{-1}$, mutta kasvusto oli selvästi heinävaltaista.

Apilanurmen orgaanisen aineen metaanintuottopotentiaali oli hieman heinänurmea matalampi, joskaan ero ei ollut aina tilastollisesti merkitsevä. Lannoituksen vaikutus oli kasvilajin vaikutusta vähäisempi. Koska apilanurmen satotaso oli heinänurmea korkeampi, se tuotti kuitenkin enemmän metaania hehtaaria kohden laskettuna. Tutkimuksessa tarkasteltiin lisäksi D-arvon, kasvuston typpipitoisuuden ja iNDF:n yhteyttä metaanintuottopotentiaaliin.

Asiasanat: puna-apila, heinänurmet, typpi, käsittelyjäännös, metaanintuottopotentiaali, sato 


\section{Johdanto}

Maatalouden ympäristövaikutusten vähentäminen ja ravinteiden tarkoituksenmukainen käyttö vaativat maatiloille ratkaisuja, jotka ovat taloudellisia ja hyödyntävät mahdollisimman tehokkaasti tilan ravinnekierron kokonaisuuden (Luostarinen 2013). Karjatiloilla karjanlanta on merkittävä osa tilan ravinnekiertoa. Lannoituskäytön ohella karjanlanta voi olla myös biokaasun raaka-aine, johon on kohtalaisen helppo yhdistää lisäsyötteitä, jotka puolestaan nostavat biokaasuntuotantoa merkittävästi. Nurmikasvit soveltuvat tähän hyvin. Ne ovat viljelyvarmoja ja tuottavat kohtalaisen suuria kuivaainesatoja. Lisäksi nurmipeitteisyys vähentää eroosiota, mistä on vesiensuojelun kannalta hyötyä erityisesti eroosioherkillä mailla. Nurmien lannoituksessa voidaan käyttää helposti biokaasulaitoksen käsittelyjäännöstä: Tämä tehostaa ravinnekiertoa oleellisesti, etenkin kun liete sijoitetaan nurmeen, jolloin ammoniakin haihtuminen estyy lähes täysin ja typpitappiot minimoituvat (Mattila 2006). Toisaalta on osoitettu, että energiatuotannon kannalta suuri kuiva-ainesatotaso on määräävä tekijä (Prochnow 2009, Seppälä 2013), ja suuria satoja tavoiteltaessa lisätypen käyttö on välttämätöntä.

Yksi vaihtoehto biokaasunurmen typpilannoitukseen on käyttää nurmipalkokasveja, joiden typensidontakyky on merkittävästi yksivuotisia palkokasveja suurempi. Toisaalta nurmipalkokasvit eivät ole optimaalisia metaanintuotantokyvyltään (Lehtomäki 2006) ja ne myös kärsivät heinänurmia herkemmin ainakin raakalietteen levityksen haitoista. Käsittelyjäännöksen vaikutuksesta ei ole riittävästi tietoa, mutta voidaan olettaa sekä käsittelyjäännöksen että lisätypen käytön vähentävän palkokasvien osuutta nurmessa. Näiden tekijöiden monimutkaisten yhdysvaikutusten vuoksi päätettiin verrata heinänurmien ja heinä-palkokasvinurmien ravinnekiertoa ja biokaasun tuotantopotentiaalia systeemitasolla. Tutkimuksen tarkoituksena oli selvittää, kuinka tehokkaasti ravinteita voidaan kierrättää, kun nurmea tuotetaan biokaasun raaka-aineeksi mahdollisimman pienillä ostopanoksilla. Tutkimuksessa selvitetään biokaasulaitoksesta saatavan käsittelyjäännöksen, lisätypen ja punaapilapitoisuuden vaikutusta nurmen satoon ja metaanintuottopotentiaaliin.

\section{Aineisto ja menetelmät}

Biokaasulaitoksen käsittelyjäännöksen, lannoituksen ja puna-apilaosuuden vaikutusta nurmen satoon ja metaanintuottopotentiaaliin tutkittiin Luonnonvarakeskuksen (Luke) Maaningan toimipisteessä Pohjois-Savossa kenttäkokeessa vuosina 2013 - 2015. Koe perustettiin vuonna 2012 suojaviljaan (Edvin - ohra) ja toteutettiin osaruutukokeena, jossa oli neljä kerrannetta. Pääruutuna kokeessa käytettiin kahta eri nurmiseosta: timotei-nurminataseosta (Tuure/Ilmari 70:30, $20 \mathrm{~kg} \mathrm{ha}^{-1}$ ) sekä punaapilapitoista timotei-nurminataseosta (Tuure/Ilmari 70:30, $15 \mathrm{~kg} \mathrm{ha}^{-1}+$ Saija $5 \mathrm{~kg} \mathrm{ha}{ }^{-1}$ ). Yksinkertaisuuden vuoksi käsittelyistä käytetään jatkossa termejä 'Heinänurmi' ja 'Apilanurmi'. Maalaji lohkolla oli multava karkea hieta. Nurmivuosia oli kolme.

Nurmivuosien lannoitus suoritettiin kokeessa neljällä eri lannoitusstrategialla 1) ei lannoitusta 2) käsittelyjäännös toiselle sadolle 3) $50 \mathrm{~kg} \mathrm{~N} 1$. sadolle ja käsittelyjäännös $+50 \mathrm{~kg} \mathrm{~N}$ toiselle sadolle ja 4) $100 \mathrm{~kg} \mathrm{~N}$ 1. sadolle ja käsittelyjäännös $+50 \mathrm{~kg} \mathrm{~N}$ toiselle sadolle. Väkilannoitetyppi annettiin Suomensalpietarina (27-0-1). Kokeessa käytettiin Luke Maaningan biokaasulaitoksen tuottamaa käsittelyjäännöstä. Naudanlietteen lisäksi biokaasulaitoksen syötteenä oli käytetty timoteinurminatarehua. Lietteestä otettiin levityshetkellä kaksi edustavaa, rinnakkaista näytettä, joista analysoitiin Viljavuuspalvelu Oy:ssä kuiva-aine, kokonaistyppi, liukoinen typpi, fosfori ja kalium.

Käsittelyjäännös sijoitettiin $5-7 \mathrm{~cm}$ syvyyteen omavalmisteisella $1 \mathrm{~m}^{3}: \mathrm{n}$ vetoisella takanostolaitesovitteisella kontilla, jossa on kaksoiskiekkovantaat. Toteutuneet levitysmäärät selvitettiin mittaamalla vetojen pituudet sekä punnitsemalla lietelevityslaitteisto ennen ja jälkeen levityksen. Käsittelyjäännöstä levitettiin keskimäärin heinänurmella $31 \mathrm{t} \mathrm{ha}^{-1}$ ja apilanurmella $32 \mathrm{t} \mathrm{ha}^{-1}$. Erilaisesta kasvurytmistä johtuen timotei-nurminataruutujen ja puna-apilapitoisten ruutujen viljelytoimenpiteet tehtiin eri aikoihin. Esimerkiksi korjuu ajoitettiin apilanurmella ja heinänurmella kasvuolosuhteiden ja kasvilajien kehitysasteen perusteella (taulukko 1).

Sadot korjattiin kaksi kertaa kesässä ja korjuun yhteydessä määritettiin kuiva-ainesato (Kasato, $\mathrm{kg} \mathrm{ka} \mathrm{ha}{ }^{-1}$. Sadosta otettiin analyysinäyte, joka kuivattiin ja analysoitiin Valion Seinäjoen aluelaboratoriossa. Näytteistä analysoitiin NIR - menetelmällä D-arvo, typpi ja sulamaton neutraalidetergenttikuitu (iNDF). Lisäksi määritettiin Ca-pitoisuus ICP-menetelmällä SeiLab Oyllä. 
Energiasato (ME-sato, GJ ha ${ }^{-1}$ ), laskettiin kaavalla $\left(\mathrm{D}\right.$-arvo $\times 0,016 \times$ Kasato $\left.\times 1000^{-1}\right)$. Metaanintuottopotentiaali määritettiin vain todennäköisesti käytäntöön parhaiten soveltuvista koejäsenistä. Sen määrittämistä varten otettiin näytteet molemmista sadoista lannoitusstrategioilta 2 ja 4 kerranteilta 1 ja 2 . Näytteet pakastettiin tuoreena eikä varastoinnissa käytetty säilöntäaineita. Näytteiden metaanintuottopotentiaali määritettiin Luken laboratoriossa Jokioisilla panoskokeilla $35^{\circ} \mathrm{C}$ :ssa (500 ml panoskoepullot, ks. Luostarinen 2013). Näytteiden määritykset tehtiin seitsemänä eri eränä, joita jokaista varten toimitettiin erillinen erä mikrobiymppiä Maaningan biokaasulaitoksesta. Laskennassa käytettiin metaanintuottopotentiaalina 30 vrk:n kohdalla saatuja tuloksia ensimmäistä erää lukuun ottamatta. Siinä metaanintuotto käynnistyi hitaammin, joten laskennassa käytettiin 40 vrk:n tuloksia. Metaanintuotto laskettiin sekä kuiva-ainetta $\left(\mathrm{m}^{3} \mathrm{CH}_{4} \mathrm{t}^{-1} \mathrm{TS}\right)$ että orgaanista kuivaainetta $\left(\mathrm{m}^{3} \quad \mathrm{CH}_{4} \quad \mathrm{t}^{-1} \quad\right.$ VS $)$ kohti. Metaanisaanto hehtaaria kohden laskettiin kaavalla Kasatox Metaanintuottopotentiaali $\left(\mathrm{m}^{3} \mathrm{CH}_{4} \mathrm{t}^{-1} \mathrm{TS}\right)$. Kasvuston apilapitoisuus arvioitiin kasvuston kalsiumpitoisuuden avulla vertaamalla sitä samalta kokeelta niittohetkellä otettujen puhtaiden apila- ja heinänäytteiden kalsiumpitoisuuteen. Säähavainnot saatiin Luke Maaningan toimipaikalla sijaitsevalta Ilmatieteenlaitoksen sääasemalta.

Kokeen tilastolliset analyysit tehtiin SAS Enterprise Guide 5.1. ohjelman MIXEDproseduurilla. Niitot käsiteltiin erikseen. Tilastomallissa nurmiseos, lannoitusstrategia, vuosi sekä kaikki näiden yhdysvaikutukset olivat kiinteitä tekijöitä, ja kerranne, kerrannexnurmiseos sekä kerrannexvuosi -yhdysvaikutukset satunnaistekijöitä. Parivertailut lannoitusstrategioiden välillä tehtiin Tukeyn testillä. Korrelaatiot laskettiin Pearsonin korrelaatiokertoimella käyttäen SAS:in CORR-proseduuria.
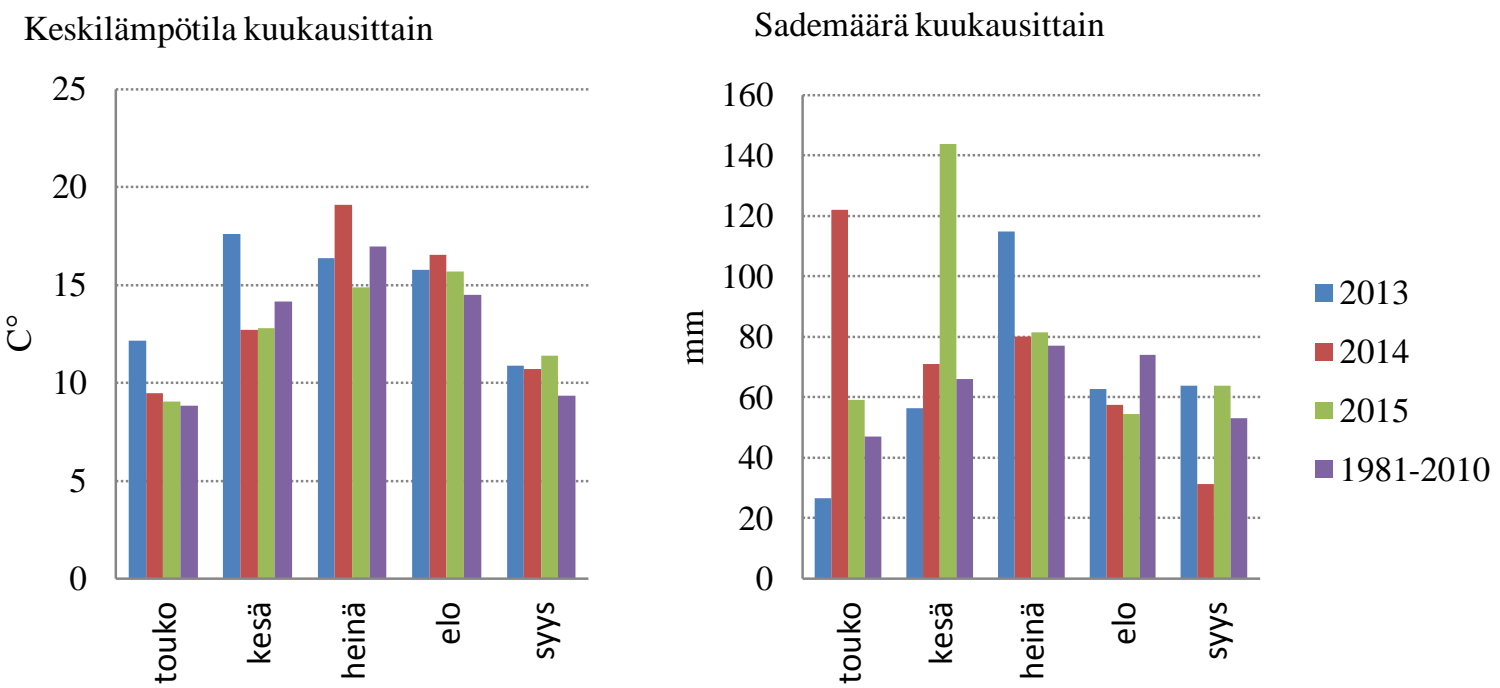

Kuva 1. Keskilämpötila ja sademäärä kuukausittain touko-syyskuussa vuosilta 2013- 2015 ja keskilämpötilat sekä sademäärä 30 - vuotisjaksolla.

Säähavainnot on esitetty kuvassa 1. Vuosi 2013 oli 30-vuotisjaksoa lämpimämpi ja sadetta kertyi toukokuussa keskimääräistä vähemmän kuin yleensä. Heinäkuussa satoi yli 100 millimetriä, muuten sademäärä kuukausittain oli lähellä keskimääräistä. Vuoden 2014 kesä oli myös lämmin ja sadetta kertyi toukokuussa yli $120 \mathrm{~mm}$, joka on huomattavasti 30- vuotisjakson keskiarvoa enemmän. Vuonna 2015 touko-heinäkuu oli kolea, mutta elo - syyskuussa kuukauden keskilämpötila oli 30-vuotista keskiarvoa korkeampi. 2015 kesäkuu oli sateinen, kasvustot kehittyivät hitaammin ja niitot ajoittuivat myöhemmälle ajankohdalle (taulukko 1).

Taulukko 1. Niittoaikataulu vuosittain.

\begin{tabular}{ccccc} 
& \multicolumn{2}{c}{ Niitto 1 } & \multicolumn{2}{c}{ Niitto 2 } \\
\cline { 2 - 5 } Vuosi & Heinänurmi & Apilanurmi & Heinänurmi & Apilanurmi \\
\hline 2013 & 13.6. & 24.6. & 26.7. & 5.8. \\
2014 & 19.6. & 25.6. & 30.7. & 6.8. \\
2015 & 22.6. & 1.7. & 5.8. & 13.8. \\
\hline
\end{tabular}


Käsittelyjäännöksen ravinnemäärät esitetään taulukossa 2. Analyysitulosten perusteella laskettiin käsittelyjäännöksestä saatu kokonaismäärä ravinteita heinänurmelle ja apilanurmelle (taulukko 3). Kokeessa käsittelyjäännöstä sekä Salpietaria saaneet lannoitusstrategiat 3 ja 4 saivat liukoista typpeä toiselle niitolle heinänurmelle $113 \mathrm{~kg} \mathrm{ha}^{-1} \mathrm{ja}$ apilanurmelle $119 \mathrm{~kg} \mathrm{ha}^{-1}$.

Taulukko 2. Käsittelyjäännöksen ravinnepitoisuudet keskiarvona vuosilta 2013-2015. Keskiarvo \pm keskihajonta, $\mathrm{n}=6$.

\begin{tabular}{lcc}
\hline Kok. $\mathrm{N}$ & $\mathrm{kg} \mathrm{t}^{-1}$ & $3,0 \pm 0,22$ \\
Liuk. $\mathrm{N}$ & $\mathrm{kg} \mathrm{t}^{-1}$ & $2,1 \pm 0,23$ \\
Liuk. N:Kok. N & & $0,72 \pm 0,119$ \\
Ka & $\%$ & $5,2 \pm 0,84$ \\
$\mathrm{P}$ & $\mathrm{kg} \mathrm{t}^{-1}$ & $0,51 \pm 0,067$ \\
$\mathrm{~K}$ & $\mathrm{~kg} \mathrm{t}^{-1}$ & $3,7 \pm 0,58$ \\
\hline
\end{tabular}

Taulukko 3. Käsittelyjäännöksen (Kj) levitysmäärät heinänurmella ja apilanurmella sekä sen sisältämät ravinnemäärät. Keskiarvo \pm keskihajonta, $n=6$.

\begin{tabular}{cccc}
\hline & & Heinänurmi & Apilanurmi \\
\hline $\mathrm{Kj}$ & $\mathrm{t} \mathrm{ha}^{-1}$ & $31 \pm 1,3$ & $32 \pm 1,2$ \\
Kok. N & $\mathrm{kg} \mathrm{ha}^{-1}$ & $94 \pm 6,1$ & $89 \pm 2,2$ \\
Liuk. N & $\mathrm{kg} \mathrm{ha}^{-1}$ & $63 \pm 7,1$ & $69 \pm 9,4$ \\
$\mathrm{P}$ & $\mathrm{kg} \mathrm{ha}^{-1}$ & $16 \pm 0,4$ & $15 \pm 3,3$ \\
$\mathrm{~K}$ & $\mathrm{~kg} \mathrm{ha}^{-1}$ & $109 \pm 22,9$ & $121 \pm 10,2$ \\
\hline
\end{tabular}

Heinänurmi ja apilanurmi niitettiin eri aikoihin, mikä vaikutti kuiva-ainesatoon sekä nurmen rehuarvoon. Satotaso erosi vuosien välillä merkitsevästi. Apilanurmen vuosittainen kokonaissato oli kaikilla käsittelyillä paras vuonna 2013 ja heinänurmen vuosittainen kokonaissato oli paras kaikilla käsittelyillä vuonna 2014. Apilanurmi tuotti kokeessa paremman kuiva-ainesadon kuin pelkkä heinänurmi (taulukko 4). Lannoituksella saatiin nostettua sekä heinänurmen että apilanurmen satoa, mutta 1. sadon N-lannoituksen nosto $50 \mathrm{~kg}$ :sta $100 \mathrm{~kg}$ :aan ei enää lisännyt satoa tilastollisesti merkitsevästi. Lannoittamattomalla heinänurmella kesän kokonaissato oli keskimäärin 5020 $\mathrm{kg} \mathrm{ka} \mathrm{ha}{ }^{-1}$, kun taas korkeimmalla lannoitustasolla satoa saatiin keskimäärin $9720 \mathrm{~kg} \mathrm{ka} \mathrm{ha-1}$. Apilanurmella ilman lannoitusta kokonaiskuiva-ainesato oli keskimäärin $8920 \quad \mathrm{~kg} \mathrm{ka} \mathrm{ha}^{-1}$. Korkeimmalla lannoitustasolla apilanurmen satotaso oli keskimäärin $11580 \mathrm{~kg} \mathrm{ka} \mathrm{ha}^{-1}$, mutta kasvusto oli selvästi heinävaltaista. ME-sato $\left(\mathrm{GJ} \mathrm{ha}^{-1}\right)$, kuten kuiva-ainesatokin, oli heikoin lannoittamattomilla koejäsenillä ja kasvoi lannoituksen myötä.

Nurmisadon sulavuuteen vaikuttavat mm. kasvuaika, lajikeominaisuudet sekä lannoitus. Heinänurmella lannoitus alensi ensimmäisen niiton D-arvoa, mutta apilanurmen D-arvo pysyi kutakuinkin samana. Toisessa sadossa D-arvo aleni sekä heinänurmessa että apilanurmessa, mutta heinänurmessa enemmän. Yleensä typpilannoituksen ei katsota alentavan D-arvoa itsessään, vaan heinänurmen osalta se vaikuttaa kasvuasteeseen: kun kaikki heinäkoejäsenet niitettiin samana päivänä, oli lannoittamaton kasvusto vielä kasvuasteeltaan nuorta, mikä näkyy myös alhaisena satona. Apilanurmessa taas apilapitoisuus laski, kun kasvustolle annettiin typpeä käsittelyjäännöksessä toiselle sadolle ja vielä enemmän, jos kasvusto sai tämän lisäksi keväällä lannoitetyppeä. Koska korjuu tapahtui apilan kehitysvaiheen mukaan, oli seoksen heinäkomponentin sulavuus jo alentunut (vrt. Kuoppala 2010), mikä alensi koko kasvuston D-arvoa.

Kasvuston apilapitoisuus arvioitiin kasvuston kalsiumpitoisuuden avulla vertaamalla sitä puhtaiden apila- ja heinänäytteiden kalsiumpitoisuuteen. Kuten odotettiin, apilaprosentti laski lannoituksen myötä. Esimerkiksi toisen sadon lannoittamattomalla ruudulla apilapitoisuus oli $71 \%$ ja laski 20 prosenttiin korkeimmalla lannoituksella (taulukko 4). Sadon typpipitoisuus kasvoi heinänurmella lannoituksen myötä merkitsevästi ja apilapitoinen nurmi oli heinänurmea typpipitoisempaa.

Nurmisadon sulamattoman kuidun (iNDF) pitoisuus oli ensimmäisessä niitossa selvästi korkeampi kuin toisessa niitossa ja apilanurmen iNDF-pitoisuus oli molemmissa sadoissa merkittävästi korkeampi kuin heinänurmen (Taulukko 4). Apilanurmella lannoitus ei vaikuttanut iNDF-pitoisuuteen, sen sijaan heinänurmella ensimmäisen sadon iNDF-pitoisuus nousi lisätyppeä annettaessa. 
Taulukko 4. Heinänurmen ja apilanurmen kuiva-ainesato, ME-sato, D-arvo, typpipitoisuus, sulamaton kuitu (iNDF), metaanintuottopotentiaali, metaanisaanto ja apilaprosentti ensimmäisestä ja toisesta sadosta vuosilta 2013-2015.

\begin{tabular}{|c|c|c|c|c|c|c|c|c|c|}
\hline \multicolumn{7}{|l|}{ 1.sato } & \multirow{2}{*}{$\begin{array}{c}\text { Metaanintuotto- } \\
\text { potentiaali } \\
\mathrm{m}^{3} \mathrm{CH}_{4} \mathrm{t}^{-1} \mathrm{VS}\end{array}$} & \multirow{2}{*}{$\begin{array}{l}\text { Metaani- } \\
\text { saanto } \\
\mathrm{m}^{3} \mathrm{CH}_{4} \mathrm{ha}^{-1}\end{array}$} & \multirow{2}{*}{$\begin{array}{c}\text { Apilan } \\
\text { osuus } \\
\%\end{array}$} \\
\hline Kas vi & Lannoitus & $\mathrm{kg} \mathrm{ka} \mathrm{ha}{ }^{-1}$ & GJ ha ${ }^{-1}$ & $\mathrm{~g} \mathrm{~kg}^{-1} \mathrm{ka}$ & $\mathrm{g} \mathrm{kg}^{-1} \mathrm{ka}$ & $\mathrm{g} \mathrm{kg}^{-1} \mathrm{ka}$ & & & \\
\hline Heinänurmi & $0 \mathrm{~N}+0 \mathrm{~N}$ & 3690 & 40,4 & 687 & 13,1 & 70,0 & - & - & - \\
\hline Heinänurmi & $0 \mathrm{~N}+\mathrm{KJ}$ & 3680 & 40,3 & 687 & 13,1 & 68,7 & 306 & 1040 & - \\
\hline Heinänurmi & $50 \mathrm{~N}+(\mathrm{KJ}+50)$ & 5460 & 58,3 & 669 & 15,8 & 85,2 & - & - & - \\
\hline Heinänurmi & $100 \mathrm{~N}+(\mathrm{KJ}+50)$ & 5690 & 60,1 & 661 & 18,6 & 93,3 & 304 & 1630 & - \\
\hline Apilanurmi & $0 \mathrm{~N}+0 \mathrm{~N}$ & 5950 & 61,1 & 646 & 18,0 & 113,3 & - & - & 49 \\
\hline Apilanurmi & $0 \mathrm{~N}+\mathrm{KJ}$ & 6110 & 62,8 & 644 & 17,9 & 114,9 & 292 & 1610 & 45 \\
\hline Apilanurmi & $50 \mathrm{~N}+(\mathrm{KJ}+50)$ & 7140 & 73,2 & 641 & 16,8 & 115,3 & - & - & 21 \\
\hline Apilanurmi & $100 \mathrm{~N}+(\mathrm{KJ}+50)$ & 7040 & 72,6 & 645 & 19,1 & 113,3 & 291 & 1900 & 24 \\
\hline Keskivirhe & & 137 & 1,25 & 3,4 & 0,50 & 2,57 & 4,5 & 39,1 & 5,1 \\
\hline \multicolumn{10}{|c|}{ Tilastollinen merkitsevyys } \\
\hline Kas vilaji & & $* * *$ & $* * *$ & $* *$ & $*$ & $* * *$ & & o & - \\
\hline Lannoitus & & $* * *$ & $* * *$ & $* * *$ & $* * *$ & $* * *$ & & $* * *$ & $* * *$ \\
\hline Vuosi & & $*$ & o & $* *$ & $*$ & $* * *$ & & & $* * *$ \\
\hline Kas vilaji $\times$ la & nnoitus & $* * *$ & $* * *$ & $* * *$ & $* * *$ & $* * *$ & & $* *$ & - \\
\hline Vuosi $\times$ kas & rilaji & $* * *$ & $* * *$ & $* * *$ & o & $* * *$ & $*$ & $* *$ & - \\
\hline \multicolumn{10}{|c|}{ Vuosi $\times$ lannoitus } \\
\hline Vuosix kas & ilaji $\times$ lannoitus & o & & $* *$ & & $* *$ & & & - \\
\hline
\end{tabular}

2.sato

\begin{tabular}{|c|c|c|c|c|c|c|c|c|c|}
\hline Kas vi & Lannoitus & $\begin{array}{c}\text { Kasato } \\
\mathrm{kg} \mathrm{ka} \mathrm{ha}^{-1}\end{array}$ & $\begin{array}{c}\text { ME-sato } \\
\text { GJ ha }\end{array}$ & $\begin{array}{c}\text { D-arvo } \\
\mathrm{g} \mathrm{kg}^{-1} \mathrm{ka}\end{array}$ & $\begin{array}{c}\mathbf{N} \\
\mathrm{g} \mathrm{kg}^{-1} \mathrm{ka}\end{array}$ & $\begin{array}{c}\text { iNDF } \\
\mathrm{g} \mathrm{kg}^{-1} \mathrm{ka}^{-}\end{array}$ & $\begin{array}{c}\text { potentiaali } \\
\mathrm{m}^{3} \mathrm{CH}_{4} \mathrm{t}^{-1} \mathrm{VS}\end{array}$ & $\begin{array}{c}\text { saanto } \\
\mathrm{m}^{3} \mathrm{CH}_{4} \mathrm{ha}^{-1}\end{array}$ & $\begin{array}{c}\text { osuus } \\
\%\end{array}$ \\
\hline Heinänurmi & $0 \mathrm{~N}+0 \mathrm{~N}$ & 1340 & 15,3 & 717 & 20,2 & 38,7 & - & - & \\
\hline Heinänurmi & $0 \mathrm{~N}+\mathrm{KJ}$ & 2500 & 28,1 & 702 & 20,0 & 42,3 & 307 & 690 & - \\
\hline Heinänurmi & $50 \mathrm{~N}+(\mathrm{KJ}+50)$ & 3800 & 42,1 & 693 & 22,5 & 48,1 & - & - & - \\
\hline Heinänurmi & $100 \mathrm{~N}+(\mathrm{KJ}+50)$ & 4030 & 44,4 & 688 & 23,3 & 52,4 & 302 & 1090 & - \\
\hline Apilanurmi & $0 \mathrm{~N}+0 \mathrm{~N}$ & 2970 & 31,3 & 660 & 26,5 & 85,2 & - & - & 71 \\
\hline Apilanurmi & $0 \mathrm{~N}+\mathrm{KJ}$ & 3530 & 37,0 & 658 & 24,4 & 79,6 & 291 & 880 & 45 \\
\hline Apilanurmi & $50 \mathrm{~N}+(\mathrm{KJ}+50)$ & 4350 & 45,4 & 653 & 23,2 & 83,1 & - & - & 20 \\
\hline Apilanurmi & $100 \mathrm{~N}+(\mathrm{KJ}+50)$ & 4540 & 46,9 & 648 & 24,1 & 87,8 & 285 & 1170 & 20 \\
\hline Keskivirhe & & 89 & 0,91 & 4,2 & 0,37 & 2,50 & 5,1 & 37,7 & 3,5 \\
\hline \multicolumn{10}{|c|}{ Tilastollinen merkitsevyys } \\
\hline \multicolumn{2}{|l|}{ Kas vilaji } & $* *$ & $* *$ & $* * *$ & $* *$ & $* * *$ & & & - \\
\hline \multicolumn{2}{|l|}{ Lannoitus } & $* * *$ & $* * *$ & $* * *$ & $* * *$ & $* * *$ & & $* * *$ & $* * *$ \\
\hline \multicolumn{2}{|l|}{ Vuosi } & $* * *$ & $* * *$ & $* * *$ & $* *$ & $* *$ & & & $* * *$ \\
\hline \multicolumn{2}{|c|}{ Kas vilaji $\times$ lannoitus } & $* * *$ & $* * *$ & $* *$ & $* * *$ & $* *$ & & & - \\
\hline \multicolumn{2}{|c|}{ Vuosi $\times$ kasvilaji } & $* * *$ & $* * *$ & $* * *$ & $* * *$ & $* *$ & & $* * *$ & - \\
\hline \multicolumn{2}{|c|}{ Vuosi $\times$ lannoitus } & $* * *$ & $* * *$ & $* *$ & $* * *$ & $* *$ & o & $*$ & \\
\hline \multicolumn{2}{|c|}{ Vuosi $\times$ kas vilaji $\times$ lannoitus } & * & $* *$ & $* *$ & $* *$ & * & & o & - \\
\hline
\end{tabular}

$* * *(\mathrm{P}<0,001), * *(\mathrm{P}<0,01), *(\mathrm{P}<0,05)$ ja o $(\mathrm{P}<0,10)$ 
Metaanintuottopotentiaali vaihteli välillä $285-307 \mathrm{~m}^{3} \mathrm{CH}_{4} \mathrm{t}^{-1}$ VS (taulukko 4). Tämä osuu hyvin nurmikasveilta mitattujen arvojen keskivaiheille (198-375 $\mathrm{m}^{3} \mathrm{CH}_{4} \mathrm{t}^{-1} \mathrm{VS}$; Prochnow ym. 2009). Apilanurmen metaanintuottopotentiaali oli vain $5-6 \%$ alhaisempi kuin vastaavasti lannoitetun heinänurmen kummassakin niitossa. Lannoituksen vaikutus oli tätäkin pienempi. Erot eivät olleet tilastollisesti merkitseviä, mutta testi ei ollut kovin voimakas, koska käytettävissä oli vain kaksi kerrannetta. Paras hehtaarikohtainen metaanisaanto määritetyistä koejäsenistä saatiin ensimmäisen sadon apilanurmelta, joka oli saanut typpeä ensimmäiselle sadolle $100 \mathrm{~kg} \mathrm{ha}^{-1}$ ja toiselle sadolle käsittelyjäännöstä ja typpeä. Käsittelystä saadun sadon kuiva-ainesato oli $7040 \mathrm{~kg} \mathrm{ha}^{-1} \mathrm{ja}$ metaanisaanto $1900 \mathrm{~m}^{3} \mathrm{CH}_{4} \mathrm{ha}^{-1}$. Toisin kuin Lehtomäen (2006) tutkimuksessa, toisen sadon apilanurmen metaanintuottopotentiaali oli samaa tasoa ensimmäisen sadon kanssa. Lehtomäki esittää tulokset panoskokeiden 30 vrk ja 50 vrk kestoaikojen jälkeen. Apilanurmi-koejäseniltä saadut tulokset vastaavat Lehtomäen timotei-puna-apilaseoksen 1. sadon 30 ja 50 vrk:n keskiarvoa $\left(296 \mathrm{~m}^{3} \mathrm{CH}_{4} \mathrm{ha}^{-1}\right)$.

Vuoden kokonaismetaanisaanto vaihteli $1740-3070 \mathrm{~m}^{3} \mathrm{CH}_{4} \mathrm{ha}^{-1}$, mikä on samaa tasoa kuin Seppälän (2013) tutkimuksessa, jossa metaanisaanto nurmikasveilla vaihteli välillä $1200-3600$ $\mathrm{m}^{3} \mathrm{CH}_{4} \mathrm{ha}^{-1}$. Vuotuinen metaanisaanto nousi $57 \%$ kun heinänurmelle annetiin $150 \mathrm{~kg}$ mineraali-N ha ${ }^{-1}$. Vastaavasti, jos lannoitusta ei lisätty mutta kasvilajiksi otettiin apila, nousi metaanisaanto $43 \%$ jolloin apilan antama hyöty vastasi noin $113 \mathrm{~kg} / \mathrm{ha}$ mineraali-N-lannoitusta. Sen sijaan apilanurmella lisätypen vaikutus hehtaarikohtaiseen metaanisaantoon oli paljon pienempi, $24 \%$. Typpilannoitus ja kasvuston apilapitoisuus lisäävät biokaasukäytössä myös syntyvän käsittelyjäännöksen typpisisältöä, ja siten lannoitusarvoa, mutta tätä vaikutusta kokeessa ei tutkittu.

Kasvien metaanintuottopotentiaali laskee kasvuasteen kehityksen myötä. Tämä johtuu pääasiassa biokaasuprosessissa heikosti hajoavien hemiselluloosan ja ligniinin määrän lisääntymisestä (Prochnow ym. 2009). Sulamaton kuitu (iNDF) kuvaa tässä tutkimuksessa tätä vaikutusta. Hyvä sulavuus (D-arvo) korreloi positiivisesti metaanintuottopotentiaalin kanssa (taulukko 5), mutta metaanisaanto hehtaarilta oli korkeammilla satotasoilla parempi alhaisemmasta D-arvosta huolimatta. Sulamattoman kuidun määrä korreloi odotetusti negatiivisesti metaanintuottopotentiaalin kanssa. Kuitenkin hehtaarikohtainen metaanisaanto oli korkean kuiva-ainesadon johdosta parempi korkeammilla iNDF-pitoisuuksilla, sillä metaanisaannon suuruus riippui lähes yksinomaan kuivaainesadosta (taulukko 5). D-arvo ja iNDF korreloivat yhtä vahvasti metaanintuottopotentiaalin kanssa, sillä niillä oli vahva keskinäinen korrelaatio (-0,97 ensimmäisessä sadossa ja $-0,94$ toisessa sadossa). Sadon typpipitoisuus ei korreloinut tilastollisesti merkitsevästi metaanintuotantopotentiaalin kanssa. Apilapitoisuus korreloi negatiivisesti metaanintuotantopotentiaalin kanssa, tosin vain ensimmäisessä sadossa.

Taulukko 5. Pearsonin korrelaatiokertoimet ja niiden merkitsevyydet kuiva-ainesadolle, metaanintuottopotentiaalille ja metaanisaannolle ensimmäisessä ja toisessa sadossa. N= havaintojen lukumäärä.

\begin{tabular}{|c|c|c|c|c|c|c|c|}
\hline & & \multicolumn{3}{|c|}{ 1. sato } & \multicolumn{3}{|c|}{ 2. sato } \\
\hline & & Kasato & $\begin{array}{l}\text { Metaanintuotto- } \\
\text { potentiaali }\end{array}$ & $\begin{array}{c}\text { Metaani- } \\
\text { saanto }\end{array}$ & Kasato & $\begin{array}{l}\text { Metaanintuotto- } \\
\text { potentiaali }\end{array}$ & $\begin{array}{c}\text { Metaani- } \\
\text { saanto }\end{array}$ \\
\hline & & $\mathrm{kg} \mathrm{ka} \mathrm{ha}^{-1}$ & $\mathrm{~m}^{3} \mathrm{t}^{-1} \mathrm{VS}$ & $\mathrm{CH}_{4} \mathrm{ha}^{-1}$ & $\mathrm{~kg} \mathrm{ka} \mathrm{ha}^{-1}$ & $\mathrm{~m}^{3} \mathrm{t}^{-1} \mathrm{VS}$ & $\mathrm{CH}_{4} \mathrm{ha}^{-1}$ \\
\hline \multirow[t]{4}{*}{$\mathrm{N}=24$} & Kasato & & $-0,62 * *$ & $0,99 * * *$ & & $-0,43 *$ & $0,97 * * *$ \\
\hline & D-arvo & $-0,76 * * *$ & $0,64 * * *$ & $-0,72 * * *$ & $-0,64 * * *$ & $0,77 * * *$ & $-0,49 *$ \\
\hline & $\mathrm{N}$ & $0,62 * *$ & $-0,26$ & $0,63 * * *$ & 0,23 & $-0,32$ & 0,18 \\
\hline & iNDF & $0,77 * * *$ & $-0,67 * * *$ & $0,73 * * *$ & $0,62 * *$ & $-0,69 * * *$ & $0,50^{*}$ \\
\hline $\mathrm{N}=12$ & Apila-\% & 0,10 & $-0,60 *$ & $-0,10$ & $-0,47$ & 0,39 & $-0,45$ \\
\hline
\end{tabular}




\section{Johtopäätökset}

Apilanurmen orgaanisen aineen metaanintuottopotentiaali oli kutakuinkin sama kuin heinänurmen. Koska apilanurmen satotaso oli vastaavan lannoituksen saanutta heinänurmea korkeampi, se tuotti kuitenkin huomattavasti enemmän metaania hehtaaria kohden laskettuna. Heinänurmen metaaninsaanto hyötyi lisätyppilannoituksesta noin kaksi kertaa niin paljon kuin apilanurmi, jossa lisätyppilannoitus alensi apilapitoisuutta. Hehtaarikohtaiseen metaanisaantoon vaikuttaa enemmän kuiva-ainesadon määrä kuin esimerkiksi sulavuus tai iNDF. iNDF ja D-arvo selittivät nurmen metaanintuotantopotentiaalia yhtä hyvin, joten D-arvo riittää kuvaamaan nurmen metaanituottopotentiaalia riittävän tarkasti. Biokaasulaitoksen käsittelyjäännöksellä lannoitettu apilanurmi on biologisesti toimiva vaihtoehto biokaasuntuotannon ravinnekierron kannalta. Hintasuhteet määrittävät sen taloudelliset mahdollisuudet.

\section{Kirjallisuus}

Kuoppala K. 2010. Influence of harvesting strategy on nutrient supply and production of dairy cows consuming diets based on grass and red clover silage. Doctoral Dissertation. MTT Science 11. MTT Agrifood Research Finland, Jokioinen, Finland. 99pp.

Lehtomäki, A. 2006. Biogas production from energy crops and crop residues. Doctoral Dissertation. Jyväskylä studies in biological and environmental science 163. University of Jyväskylä. Jyväskylä, Finland. 91pp.

Luostarinen, S. (toim.) . 2013. Biokaasuteknologiaa maatiloilla I. Biokaasulaitoksen hankinta, käyttöönotto ja operointi- käytännön kokemuksia MTT:n maatilakohtaiselta laitokselta. MTT Raportti 113. $96 \mathrm{~s}$.

Mattila, P. 2006. Ammonia emissions from pig and cattle slurry in the field and utilization of slurry nitrogen in crop production. Doctoral Dissertation. Agrifood Research Reports 87. MTT Agrifood Research Finland, Jokioinen, Finland. 136pp.

Prochnow, A., Heiermann, M., Plöchl, M., Linke, B., Idler, C., Amon, T. \& Hobbs, P.J. 2009. Bioenergy from permanent grassland - a review: 1. Biogas. Bioresource Technology 100:4931-4944

Seppälä, M. 2013. Biogas production from high-yielding energy crops in Boreal conditions. Doctoral Dissertation. Jyväskylä studies in biological and environmental science 266. University of Jyväskylä. Jyväskylä, Finland. 89pp. 